\title{
Kesehatan Lingkungan Kerja Home Industri Tembaga Kotagede Yogyakarta
}

\author{
Nur Ainun Simangunsong
}

\begin{abstract}
The health of work environment is the right of worker and the vital facility for optimal working productivity. As the right, the obligation of each work place create the health for work environment and it protects the health of workers through using approach maintenance, the health improvement (promotive the ill recovery (curative) and the health restoration (rehabilitation) taken holistically, comprehensively and continuously.
\end{abstract}

\section{Pendahuluan}

Cita-cita bangsa Indonesia sebagaimana tercantum dalam Pembukaan Undangundang Dasar 1945 diantaranya adalah melindungi segenap bangsa Indonesia dan seluruh tumpah darah Indonesia, memajukan kesejahteraan umum dan mencerdaskan kehidupan bangsa. Dalam rangka mencapai cita-cita bangsa tersebut, diselenggarakan pembangunan nasional di semua bidang kehidupan secara berkesinambungan dalam satu rangkäian yang menyeluruh, terpadu, dan terarah. Atau meminjam terminologi hukum lingkungan, bahwa pola pembangunan harus berorientasi pada pembangunan berkelanjutan yang berwawasan lingkungan hidup, dilakukan dengan penuh upaya sadar dan terencana, yang memadukan lingkungan hidup termasuk sumber daya, ke dalam proses pembangunan untuk menjamin kemampuan, kesejahteraan, dan mutu hidup generasi masa kini dan generasi masa depan.
Di era pembangunan, di samping tumbuh dan berkembang industri-industri besar dan menengah, juga terdapat pertumbuhan berbagai bentuk usaha home industri. Prosentasi peningkatan pendapatan dan kemajuan usaha home industri ini diperlihatkan dengan daya saing dan daya tahannya di tengah terpaan arus krisis moneter pada pertengahan 1998 yang lalu.

Di Daerah Istimewa Yogyakarta misalnya, banyak ditemukan jenis usaha ini mulai dari gerabah, batik, tas, sandal, bunga, perak, sampai tembaga. Salah satu daerah yang menyemarakkan jenis usaha ini adalah Kotagede. Sebagai salah satu komoditi andalannya adalah kerajinan tembaga di samping jenis perak. Jenis logam ini lebih banyak diminati oleh para pengrajin karena tidak membutuhkan modal yang terlalu besar dan bahannya pun mudah didapat, meskipun prosesnya lebih keras ketimbang perak. 
Mudah dan murahnya industri jenis logam tembaga ini sehingga menarik perhatian \pm 80 $\%$ masyarakat Kotagede untuk menanamkan keseriusannya pada jenis usaha ini. Akan tetapi dengan maraknya masyarakat menggeluti usaha ini maka tidak tertutup kemungkinan ruang udara di sekitar lingkungan kejja akan ikut tercemari akibat proses produksi tembaga tersebut. Jika itu terjadi sudah barang tentu subjek yang paling tercemari adalah para pekerja itu sendin. Efek yang ditimbulkan akibat proses pembakaran tembaga dan zat-zat kimia yang digunakan dapat berupa kelainan saluran pernafasan (bronkhopulmoner), paru-paru, dan pnemonitis kimia. Bahkan kelebihan menghirup percikan abu tembaga dari proses pembakaran dalam tingkat tertinggi dapat mengakibatkan gangguan pernafasan akut yang .mengakibatkan meninggal dunia.

Dari uraian di atas, permasalahan menarik yang perlu diteliti adalah sebagai berikut. Bagaimanakah keadaan kesehatan lingkungan kerja home industri tembaga di Kotagede Yogyakarta? Bagaimanakah upaya menjamin kesehatan lingkungan kerja dan perlindungan kesehatan pekerja home industri tembaga tersebut?

\section{Pengertian Kesehatan, Lingkungan, dan Kesehatan Lingkungan Kerja}

Agar mendapatkan pengertian yang komprehensif mengenai yang dimaksud Kesehatan Lingkungan Kerja, di bawah ini akan diuraikan ketiga term tersebut.
Istilah kesehatan dalam UU No. 23 Tahiun 1992 (UUK), Bab I Pasal 1, butir (1) memiliki pengertian yaitu "suatu keadaan sejahtera dari badan, jiwa, dan sosial yang memungkinkan setiap orang hidup produktif secara sosial dan ekonomis."

Menurut Organisasi Kesehatan Sedunia, kesehatan mengandung pengertian "health is defined as a state of complete physical, mental, and social wellbeing and note merely the absence of disease or infimity."

Kedua pengertian kesehatan di atas secara esensil mengandung pengertian yang sama dan memberi makna yang sangat luas pada kata kesehatan. Yaitu totalitas sejahtera din yang meliputi jasmaniah, rohaniah (spritual), dan sosial. Berdasarkan defenisi tersebut, seseorang belum dianggap sehat sekalipun ia tidak berpenyakit jiwa dan ataupun raga. Orang tersebut masih harus dinyatakan sehat secara sosial. Dengan demikian, kesehatan tidak hanya diukur dari penampakan sehat jasmaniahnya semata, melainkan terkait pula pemancaran rohaniahnya melalui perilaku dan interaksi sosial. Menurut Juli Soemirat Slamet, ${ }^{2}$ dengan defenisi kesehatan (UUK) demikian cakupan bidang kesehatan akan membawa implikasi ke taraf penyelenggaraan kesehatan secara kualitatif. Sebagai perbandingan, American Public Health Association (APHA), Emerson and Luginbuhl (EM), dan World Health Organization (WHO) telah merumuskan konsep kesehatan dalam The Basic Six yang meliputi: ${ }^{3}$

\footnotetext{
1 Juli Soemirat Slamet, Kesehatan Lingkungan (Yogyakarta: Gadjah Mada University Press, 2002), hlm. 4.

${ }^{2}$ Ibid., him. 5

${ }^{3}$ H.R. Laevell dan E.G. Clarck, dalam Juli Soemirat Slamet, ibid., hlm. 7.
} 


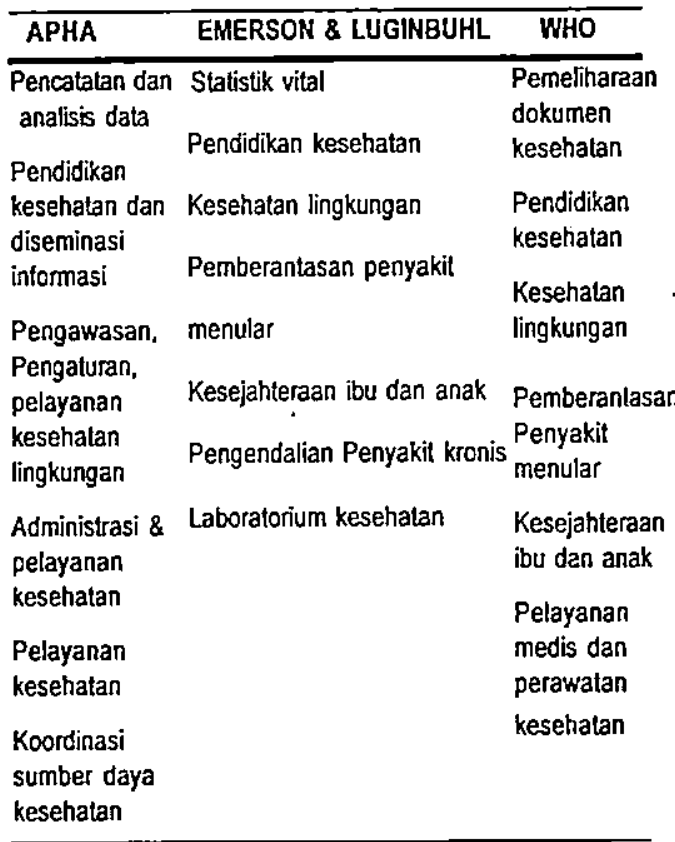

Dalam UUK Bab V, Pasal 11, penyelenggaraan kesehatan dilaksanakan melalui 15 kegiatan:

1. kesehatan keluarga;

2. perbaikan gizi;

3. pengamanan makanan dan minuman;

4. kesehatan lingkungan;

5. kesehatan kerja;

6. kesehatan jiwa;

7. pemberantasan penyakit;

8. penyembuhan penyakit dan pemulihan kesehatan;

9. penyuluhan kesehatan masyarakat;

10. pengamanan sediaan farmasi dan alat kesehatan;

11. pengamanan zat adiktif;

12. kesehatan sekolah;

13. kesehatan otahraga;

14. pengobatan tradisional;

15. kesehatan matra. (garis miring dari Penulis). ..
Mulai Pelita V kegiatan pokok kesehatan tersebut yang tadinya ada 15 dinaikkan menjadi 18. Kegiatan tersebut meliputi: kesejahteraan ibu dan anak, keluarga berencana, gizi, kesehatan lingkungan, pemberantasan penyakit, penyuluhan kesehatan, pengobatan dan penanggulangan kecelakaan, perawatan kesehatan masyarakat, usaha kesehatan sekolah, kesehatan gigi dan mulut, kesehatan jiwa, pemeriksaan laboratorium sederhana, pencatatan dan pelaporan, kesehatan mata, kesehatan olah raga, kesehatan pekerja non formal, pembinaan pengobatan tradisional, peningkatan upaya dana sehat masyarakat. Dari macam kegiatan kesehatan ini terlihat bahwa konsep kesehatan di Indonesia memiliki wilayah cakupan yang sàngat luas dan materiilnya diuraikan secara kualitatif dan kategoris.

Sedangkan pengertian lingkungan secara ekologis adalah segala sesuatu yang ada di sekitarnya, baik berupa benda hidup, benda mati, benda nyata ataupun abstrak, termasuk manusia lainnya, serta suasana yang terbentuk karena terjadinya interaksi di antara elemenelemen di alam tersebut. Lingkungan dalam pengertian ini tidak mengenal batas wilayah, baik wilayah negara maupun administratif. Misalnya, air tak dapat dipisahkan dari udara, karena di dalam udara terdapat uap-uap ataupun bintik-bintik air. Udarapun terdapat di dalam tanah. Karenanya, apabila udara mengandung banyak sulfur dioksida, maka bila hujan turun, maka air hujan akan bersifat asam, dan air permukaan menjadi asam pula. Benda hidup tak dapat dipisahkan dari benda mati. Demikian pula dengan manusia dan hewan yang tergantung pada berbagai benda tidak hidup untuk kelangsungan hidupnya, seperti air, udara, tanah, di samping benda hidup 
seperti berbagai sayuran dan dagingdagingan. Atas dasar itulah orang mengatakan bahwa lingkungan itu tidak mengenal batasan (bounderies).

Kalau dimensi lingkungan secara ekologis tampak tak terbatas, maka dalam perspektif UU No. 23 Tahun 1997 (UUPLH), ruang lingkup lingkungan hidup Indonesia dibatasi oleh ruang dan tempat Negara Kesatuan Republik Indonesia berdaulat dan beryurisdiksi. ${ }^{4}$ Batasan ini dapat dimengerti karena lingkungan hidup berkaitan dengan pengelolaan harus jelas batas wilayah wewenang pengelolaannya. Lingkungan hidup Indonesia tidak lain adalah wilayah, yang menempati posisi silang antara dua benua dan dua samudera dengan iklim tropis dan cuaca serta musim yang memberikan kondisi alam dan kedudukan dengan peranan strategis yang tinggi nilainya sebagai tempat rakyat dan bangsa Indonesia menyelenggarakan kehidupan bermasyarakat, berbangsa, dan bernegara dalam segala aspeknya. Dengan kata lain, Wawasan Nusantara menjadi frame dan memiliki kedudukan yang signifikan di dalam menyelenggarakan pengelolaan lingkungan hidup Indonesia.

Dalam Bab 1, Pasal 1 butir (1) UUPLH dijelaskan, lingkungan hidup adalah "kesatuan ruang dengan semua benda, daya, keadaan dan makhluk hidup, termasuk manusia dan perilakunya, yang mempenganuhi kelangsungan perikehidupan dan kesejahteraan manusia serta makhluk hidup lainnya." Defenisi tersebut mengandung pengertian, lingkungan hidup sebagai suatu ekosistem terdiri atas berbagai subsistem yàng saling mempengaruhi dan mempunyai aspek sosial, budaya, ekonomi, dan geografi dengan corak ragam yang berbeda-beda serta daya dukung dan daya tampung lingkungan hidup yang berbeda pula. Karena lingkungan hidup sebagai suatu ruang memiliki daya tampung dan ketahanan yang sangat terbatas maka keselarasan, keserasian, dan keseimbangan subsistem perlu diperhatikan. Pergeseran posisi dan pola interaksi di antara subsistem tersebut akan mempengaruhi ketahanan lingkungan hidup itu sendiri. Demikian juga halnya faktor-faktor eksternal seperti komponen-komponen bahan dan proses industrialisasi dalam kadar berlebihan akan mengandung sensitivitas ting: terhadap lingkungan hidup berupa pencemaran. Pengotoran lingkungan dan sumber daya alam yang sangat dibutuhkan untuk kehidupan seharihari akan mengakibatkan manusia aka s mengalami gangguan kesehatan karenanya. Dari uraian di atas dapat dipahami bahwa kelangsungan hidup manusia sangat tergantung pada kesehatan dan lingkungannya. Keberlangsungan hidup manusia sangat ditentukan oleh pengendalian manusia terhadap kesehatan lingkıngannya.

Dalam kepustakaan public health, istilah kesehatan lingkungan disebut environment health. Pada mulanya, dalam perkembangan ilmu kesehatan, istilah environment menyangkut environment sanitations, hygiene atau fersonel hygiene yang membatasi terhadap semua usaha yang bertujuan untuk mengadakan pencegahan ataupun penolakan terhadap faktor-faktor hidup yan: dapat menimbulkan

4Koesnadi Hardjasoemantri, Hukum Tata Lingkungan (cet. ke-14) (Yogyakarta: Gadjalı Mada University Press, 1999), him. 69 dan 576. 
suatu penyakit secara epidemologis. ${ }^{5}$ Lingkungan ini secara garis besar dibagi menjadi lima.

1. Lingkungan fisis sebagai media lingkungan yang mati, atau non biotis;

2. Lingkungan biologis yang hidup (biotis), seperti dunia fauna dan flora kita;

3. Lingkungan sosial ekonomi;

4. Lingkungan sosio kultural;

5. Lingkungan sosio politis.

Dalam perkembangan berikutnya, konsep environment health telah mencakup pengertian dan lingkup yang lebih luas, tidak terbatas pada materi hygeine saja tetapi terhadap semua sistem-sistem pencegahan, monitoring, langkah-langkah pengamanan, dan lain sebagainya. Environment health meliputi prinsip-prinsip usaha untuk ineniadakan atau setidak-tidaknya menguasai icktor lingkungan yang dapat menimbulkan penyakit, melalui kegiatan water sanitation, food sanitation, sewarage and excrete disposal, air sanitation, vector and rodent controle, 1:gier.e perumahan dan halaman. Kegiatankegiatan itu kemudian dalam perkembangan environment health digunakan sebagai dasardasar dan diperluas untuk memenuhi lapangan atau kesehatan lingkungan. ${ }^{6}$ Dari uraian tersebut dapat disimpulkan bahwa environment health atau kesehatan lingkungan mengandung pengertian kesatuan ruang yang berkualitas sejahtera jasmani, rohani, dan sosial serta penerapan prinsip-prinsip usaha preventif untuk meniadakan atau setidaktidaknya mengudsai faktor lingkungan yang dapat menimbulkan penyakit.

Dalam Penjelasan Pasal 22 ayat (1) UUK dijelaskan, kesehatan lingkungan diselenggarakan untuk mewujudkan derajat kesehatan masyarakat yang optimal, yang dapat dilakukan, antara lain, melalui peningkatan sanitasi lingkungan, baik padà lingkungan tempatnya maupun terhadap bentuk atau wujud substantifnya yang berupa fisik, kimiawi, atau biologis, termasuk perubahan perilaku. Kualitas lingkungan yang sehat adalah keadaan lingkungan yang bebas dari risiko yang membahayakan kesehatan dan keselamatan hidup manusia.

Dalam Pasal 22 ayat (2) dijelaskan, kesehatan lingkungan dilaksanakan terhadap tempat umum, lingkungan pemukiman, lingkungan kerja, angkutan umum, dan lingkungan lainnya. Lingkungan kerja yang dimaksud misalnya perkantoran, kawasan industri atau yang sejenisnya. Kesehatan lingkungan kerja diselenggarakan agar setiap pekerja dapat bekerja secara sehat tanpa membahayakan diri sendiri dan masyarakat sekelilingnya, agar diperoleh produktivitas kerja yang optimal, sejalan dengan program perlindungan tenaga kerja. Dengan demikian kesehatan lingkungan kerja pada hakikatnya merupakan penyerasian kapasitas kerja, beban kerja, dan lingkungan kerja.

\footnotetext{
${ }^{5}$ Secara sederhana, sanitation mengandung pengertian udara, di mana manusia menghirup dan memberikan kesempatan Demafas untuk hidup, mediaair, di mana manusia minum atau pergunakan mandi, cuaca dan iklim, matahari dan penerangan lainnya, perumahan tempat manusia berteduh dan lainnya. Lihat Slamet Ryadi, Kesehatan Lingkungan (Surabaya: Karya Anda, 19840), him. 68.

${ }^{6} \mathrm{Hbid}$.
} 
Aspek Yuridis Kesehatan Li.ngkungan

Kerja dan Perlindungan Kesehatan Pekerja

Dalam meningkatkan kemampien untuk hidup sehat bagi setiap penduduk agar dapat inewujudkan derajat kesehatan masyarakat yang optimal sebagai salah satu unsur kesejainteraan umum dari tujuan nasional, perlu dilaksanakan melalui pembangunan kesehatan. Pembangunan kesehatan merupakan bagian integral dari pembangunan nasional dan keberhasilan pembangunan di bidang kesehatan akan memberikan saham bagi pemantapan sumber daya manusia yang bersama-sama dengan hasil pembangunan lainnya secara terpadu dan dapat memantapkan tingkat ketahanan nasional.?

Pembangunan kesehatan lingkungan kerja sebagai salah satu upaya pembangunan nasional diarahkan guna tercapainya kesadaran, kemauan, dan kemampuan untuk hidup sehat bagi setiap pengusaha dan pekeja agar dapat mewujudkan derajat kesehatan yang optimal. Dalam rangka tujuan ini pembangunan kesehatan lingkungan keja diorientasikan pada peningkatan mutu sumber daya manusia dan lingkungan yang saling mendukung dengan pendekatan paradigma sehat, yang memberikan prioritas pada upaya peningkatan kesehatan, pencegahan, penyembuhan, pemulihan, dan rehabilitasi. ${ }^{8}$ Berangkat dari hal itu pemerintah harus mengembangkan sistem jaminan sosial tenaga kerja untuk mendapatkan perlindungan. keamanan, dan keselamatan kerja yang memadai, yang pengelolaannya melibatkan pekerja, pemerintah, dan perusahaan.
Dalam Pasal 23 ayat ( $\hat{)}$ ) UUK ditegaskan, setiap tempat kerja wajib menyelenggarakan kesehatan kerja. Tempat kerja adalah tempat yang terbuka atau tertutup, bergerak atau tidak bergerak, yang dipergunakan untuk memproduksi barang dan jasa, oleh satu atau beberapa orang pekerja. Akan tetapi dalam Penjelasan ayat (3) ini disebutkan bahwa hanya tempat kerja yang mempunyai karyawan minimal 10 orang yang wajib menyelenggarakan kesehatan kerja. Dengan demikian menurut ketenluan ini home-home industri tidak wajib menyelenggarakan kesehatan kerja, karena jumlah karyawan home industri berkisar 4 sampai 6 orang. Penjelasan ini terlihat rancu jika dikembalikan pada makna kesehat : sebagai suiatu hak dan asas-asas yang melandasi bangunan UUK itu sendiri. Apabila persepsi dasar pengecualian tersebut adalah ekonomis karena keterbatasan modal. Hal ini tiơak berarti ada persepsi dan perlakuan yang diskriminatif untuk mengupayakan kesehatan lingkungan dan perlindungan kesehatan pekerja. Sebab persoalan kesehatan adalah persoalan hak asasi manusia yang wajib dilindungi oleh setiap pemilik usaha. Dalam Pasal 4 disebutkan secara tegas, setiap orang memiliki hak yang sama dalam memperoleh derajat kesehatan yang optimal, maka dimafhum-kan setiap orang berkewajiban pula untuk ikut serta dalam memelihara dan meningkatkan derajat kesehatan baik perseorangan, keluarga, dan lingkungannya (Pasal 5).

Ditinjau dari sudut asas, pembangunan kesehatan pada asasnya adil dan merata,

\footnotetext{
'Lihat Penjelasan Umum UUK

- Garis-garis Besar Haluan Negara 1999-2004 yang dikukuhkan dalam Tap MPR No. IV/MPR/1999.
} 
perikehidupan dalam keseimbangan serta perikemanusiaan berdasarkan Ketuhanan Yang Maha Esa. Artinya, dalam penyelenggaraan kesehatan harus dapat memberikan pelayanan yang adil dan merata kepada segenap lapisan masyarakat. Penyelenggaraan kesehatan harus dilaksanakan secara seimbang antara kepentingan individu dan masyarakat, antara fisik dan mental, antara materiel dan spiritual. Dan terakhir, asas yang paling fundamen yaitu bahwa penyelenggaraan kesehatan harus dilandasi atas perikemanusiaan yang berdasarkan Ketuhanan Yang Maha Esa dengan tidak membeda-bedakan golongan, agama, dan bangsa. Kesehatan merupakan hak universal dan normatif, oleh karena itu tidak selayaknya keberlakuan dan eksistensinya dibatasi. Berdasarkan asas ini sesungguhnya tidak relevan terlalu mempersyaratkan secara kategorik penyelenggaraan kesehatan kerja bagi setiap tempat kerja. Karena hal ini dapat menjadi alat justifikasi dan manipulasi pengusaha untuk menghindari tanggung jawabnya. Yang terpenting dan relevan di sini adalah bagaimana ketentuan normatif ini tetap dijalankan dengan langgam yang fleksibel sesuai bentuk, tingkatan dan jenis usahanya. Dengan demikian setiap tempat kerja tanpa kecuali b̈erkewajiban menyelenggarakan kesehatan lingkungan kerja dan perlindungan kesehatan pekerja.

Hal senada juga dipertegas dalam Pasal 5 UUPLH bahwa,

ayat (1) setiap orang mempunyai hak yang sama atas lingkungan hidup yang baik dan sehat; ayat (2) setiap orang mempunyai hak atas informasi lingkungan hidup yang berkaitan dengan peran dalam pengelolaan lingkungan hidup; ayat (3) setiap orang mempunyai hak untuk berperan dalam rangka pengelolaan lingkungan hidup sesuai dengan peraturan perundangundangan yang berlaku.

Ketentuan ini merupakan penegasan dari ketentuan UUK di atas perihal hak kesehatan secara menyeluruh yang harus diberikan kepada setiap orang. Kata "setiap orang" mengindikasikan subjek umum yang tidak dibatasi oleh identitas sosial atau struktur jabatan apapun. Dengan demikian, pekerja sebagai subjek tertentu yang selalu lekat dan dekat dengan mesin industri juga mempunyai hak yang sama dan oleh karena itu harus mendapat perlakuan perlindungan yang sama pula.

Dalam perspektif UUPLH, salah satu bentuk hak lingkungan yang sehat adalah pemberian informasi lingkungan dan kesehatan yang benar dan objektif (Pasal 6). Dalam penjelasan Pasal 6 ini, hak atas informasi lingkungan hidup merupakan suatu konsekuensi logis dari hak berperan dalam pengelolaan lingkungan hidup yang berlandaskan pada asas keterbukaan. Hak atas informasi lingkungan hidup akan meningkatkan nilai dan efektivitas peranserta dalam pengelolaan lingkungan hidup, di samping akan membuka peluang bagi masyarakat untuk mengaktualisasikan haknya atas lingkungan hidup yang baik dan sehat. Informasi lingkungan hidup sebagaimana dimaksud pada ayat di atas dapat berupa data, keterangan, atau informasi lain yang berkenaan dengan pengelolaan lingkungan hidup yang menurut sifat dan tujuannya memang terbuka untuk diketahui, seperti dokumen analisis mengenai dampak lingkungan hidup, laporan dan evaluasi hasil pemantauan lingkungan hidup, baik pemiantauan penataan maupun 
pemantauan perubahan kualitas lingkungan hidup. Pemberian informasi oleh pengusaha kepada para pekerja sebagai satu langkah sosialisasi dunia industri dan pengenalan dampak proses produksi. Kedudukan informasi ini sangat penting karena menyangkut banyak hal di antaranya sebagai sumber pengetahuan seputar hak-hak normatif pekerja dan sarana preventif mencegah kecelakaan kerja.

Upaya mewujudkan kesehatan lingkungan kerja ditentukan oleh efektivitas kerja sama antara pekerja, pengusaha dan pemerintah. Berkaitan dengan peran pemerintah, dalam Pasal 9 UUK menyatakan pemerintah bertanggung jawab untuk meningkatkan derajat kesehatan masyarakat. Peran pemerintah dalam hal ini meliputi pembinaan dan pengawasan. Selanjutnya dalam Pasal 74 dijelaskan bahwa tugas pembinaan tersebut diarahkan untuk:

1. mewujudkan derajat kesehatan masyarakat yang optimal;

2. terpenuhinya kebutuhan masyarakat akan pelayanan dan perbekalan kesehatan yang cukup, aman, bermutu, dan terjangkau oleh seluruh lapisan masyarakat;

3. melindungi masyarakat terhadap segala kemungkinan kejadian yang dapat menimbulkan gangguan dan atau bahaya terhadap kesehatan;

4. memberikan kemudahan dalam rangka menunjang peningkatan upaya kesehatan;

Guna menunjang keberhasilan tugas dan fungsi pembinaan tersebut, selanjutnya oleh Menteri Kesehatan ditetapkan sebuah Keputusan No. 149/MENKES/SK/II/1994 tentang Dewan Pembina Program Jaga Mutu Pelayanan Kesehatan. Keputusan ini berisi pembentukan struktur organisasi, koordinasi, perumusan materi dan pelaksanaan program jaga mutu pelayanan kesehatan. Adapun tugas-tugas dewan pembina ini secara materiil disebutkan sebagai berikut:

a. Membantu menteri dalam merumuskan kebijaksanaan pengembangan program jaga mutu.

b. Memberikan saran dan pertimbangan pada menteri tentang kegiatan jaga mutu.

c. Menyusun strategi pengembangan program jaga mutu;

d. Menyusun program kerja pengembangan program jaga mutu;

e. Menyusun pedoman-pedoman penyelenggaraan program jaga mutu;

f. Memantau pedoman-pedoman penyeleriggaraan program jaga mutu.

Karena ruang lingkup persoalan kesehatan lingkungan kerja sangat kompleks maka pelaksanaan tugas Dewan Pembina Program Jaga Mutu tetap melibatkan berbagai unsur seperti organisasi profesi dan organisasi kemasyarakatan lain. Unsur internal pemerintah sendiri terdiri dari dinas tenaga kerja dan transmigrasi, perindustrian, pertanian, perikanan dan sebagainya. sedangkan unsur organisasi kemasyaraka!an yang dimaksud biasanya diderivasikan kepada organisasi sosial masyarakat ataupun pihak badan usaha swasta.

Derivasi penyelenggaraan pelayanaan kesehatan berkaitan dengan upaya menjaga kesehatan lingkungan kerja dan perlindungan kesehatan pekerja oleh pihak swasta telah diatur berdasarkan UU No. 1 Tahun 1970 tentang Keselamatan Kerja. Sebagai tindak lanjut dari ketentuan ini kemudian oleh Menteri Tenaga Kerja dan Transmigrasi ditetapkan Keputusan No. Kep. 241/MEN/2000 tentang Petunjuk Pelaksanaan Bulan Keselamatan 
dan Kesehatan Kerja Tahun 2001, yang esensinya menegaskan bahwa dalam rangka meningkatkan peran serta dan kepedulian pengusaha, pimpinan perusahaan, tenaga kerja, lembaga swadaya masyarakat, praktisi $\mathrm{K} 3$, Asosiasi-asosiasi, departemen teknis ataupun instansi non departemen di bidang $\mathrm{K} 3$, dalam menuju kemandirian pelaksanaan bulan $v$ ampanye Nasional dan penerapan $\mathrm{K} 3$ di masa depan maka Pemerintah dalam hal ini Depnaker telah menetapkan kebijakan pelaksanaan kampanye dari kampanye nasional K3 menjadi Gerakan Nasional K3. Penetapan petunjuk tersebut sekaligus untuk keseragaman pelaksanaan baik di tingkat Pusat maupun Daerah Otonom dan perusahaan. Petunjuk ini merupakan pedoman bagi setiap pimpinan Departemen, Lembaga Non Departemen/BUMN/Instansi Swasta, DK3N, Serikat Kerja, Apindo, PT. Jamsostek, perusahaan dan masyarakat lainnya secara füngsional baik di tingkat Pusat maupun daerah otonom. Dengan kata lain, petunjuk torsebut merupakan dasar perkenan bagi perusahaan swasta untuk menyelenggarakan upaya kesehatan kerja dan segala sesuatunya yang berkaitan dengan pencegahan dan pengobatan penyakit yang dapat timbul akibat kerja meḷalui program preventive medicine (kedokteran pencegahan) yang dibentuk sendiri. Dengan spirit kesadaran untuk menderivasikan sistem pelayanan kesehatan kerja di berbagai lingkungan instansi pemerintah maupun swasta ini menunjukkan bahwa langkah pro aktif pemerintah melalui sejumlah aturan kebijaksanaan dapat dianggap responsif dan aspiratif dengan kebutuhan sosial pekerja. Hanya saja disayangkan Gerakan Nasional $K 3$ ini hanya sebatas pada implementasi di tingkat perusahaan- perusahaan besar sedangkan usaha kecil/ menengah belum tersentuh. Seperti data yang terlihat dalam !:poran yang diungkapkan dalam Kepmennakertrans tersebut di bawah ini. Berdasarkan informasi, pelaksanaan K3 melalui sistem manajemen $\mathrm{K} 3$ dan terlaksananya audit SMK3 dari tahun ke tahun semakin meningkat dan secara akumulasi sebanyak 237 perusahaan telah diaudit. Datadata kecelakaan yang terjadi dalam 3 tahun terakhir cenderung menurun di mana pada 1997 terjadi 95.759 kasus kecelakaan kerja dengan jaminan yang dibayar sebesar Rp. 70 milyar dan 1998 terjadi penurunan menjadi 88.336 kasus kecelakaan kerja dengan jaminan yang dibayarkan sebesar 76 milyar dan untuk 1999 terjadi kembali penurunan menjadi 80.542 kasus kecelakaan kerja dengan jaminan yang dibayarkan sebesar Rp. 83 milyar. Di satu sisi langkah ini dapat dianggap sebagai langkah maju, akan tetapi di sisi lain lebih terlihat elitis. Karena pelaksanaan program ini hanya menyentuh lavel tertentu saja, sementara di kalangan usaha kecil dan home-home industri tidak. Dilihat dari komposisi strukturnya yakni P2K3 sebanyak 14.671 unit, PJK3 sebanyak 197 perusahaan, Badan Audit sebanyak 1 perusahaan serta telah ditunjuknya Ahli K3 umum sebanyak 1334 orang dan pencapaian nihil kecelakaan kerja oleh 409 perusahaan. Memang tidak dapat berharap banyak kalau sistem manajemen sampai pada level homehome industri.

Faktor lain yang mempengaruhi kesehatan lirgkungan dan produktivitas kerja adalah waktu kerja dan sistem pengupahan. Dalam Instruksi Menteri Tenaga Kerja No. INS03/M/BW/1991 tentang Peiaksanaan Waktu Kerja dan Waḱtu !stirahai, mer:gaskan bahwa 
setiap perusahaan mengupayakan agar tidak memperkerjakan tenaga kerja lebih dari 9 jam sehari dan 54 jam seminggu. Apabila suatu perusahaan terdapat mempekerjakan tenaga kerja melebihi dari waktu yang telah ditentukan - sebagaimana butir 3 di atas-maka perusahaan tersebut harus mengarahkan sebagaimana dimaksud pada butir 3 tersebut dan memperhitungkân upah lembur berdásarkan Keputusan Menteri Tenaga Kerja No. Kep. 72/Men/ 1984/jo Keputusan Menteri Tenaga Kerja No. 608/Men/1986. Akan tetapi kendalanya, karena segi formal aturan ini berbentuk instruksi maka realitasnya ketentuan ini sering tidak diindahkan. Apalagi dalam butir 6 dijelaskan bahwa “...agas instruksi ini dilaksanakan dengan penuh tanggung jawab." Dengan demikian titik tekannya hanya bersifat himbauan moral semata.

Persoalan upah dalam dunia usaha dan tenaga kerja merupakan persoalan klasik dan terus bergulir sepanjang masa. Hal ini mengingat, upah memiliki dimensi sosial yang terkait dengan aspek kesejahteraan hidup dan kehidupan manusia. Dari sudut dimensi ekonomi, upah merupakan hak pekerja sebagai konsekuensi dari jasa yang ia berikan, sementara dalam dunia usana dalam rangka menggenjot tingkat produksi dan keuntungan yang tinggi, setiap badan usaha selalu membutuhkan tenaga keja dengan upah yang relatif murah. Bahkan terkadang, seringkali perusahaan memiliki orientasi kapital yang berlebihan dan menekan pekejja pada posisi yang terjepit. Perilaku ini jelas bertentangan dengan norma dasar UUD 1945. Dalam Pasal 27 ayat (2) UUD 1945 ditegaskan, "Tiap-tiap warga negara berhak atas pekerjaan dan penghidupan yang layak bagi kemanusiaan." Selanjutnya dalam Pasal 28 D butir (2) disebutkan "Setiap orang berhak untuk bekerjä serta mendapat imbalan dan perlakuan yang adil dan layak dalam hubungan kerja. ${ }^{\text {"9 }}$ Dan terakhir dalam Pasal $28 \mathrm{H}$ butir (1: ditambahkan "Setiap orang berhak hidup sejahtera lahir dan batin, bertempat tinggal, dan mendapatkan lingkungan hidup yang baik dan sehat serta berhak memperoleh pelayanan kesehatan. ${ }^{.10}$ Apabila dicermati pasal-pasa; mengenai hak di atas, meskipun ada perbedaan teoritis antara Pasal 27 dengan Pasal 28 akan tetapi keduanya tetap memiliki orientasi perlindungan yang sama pada hak-hak pekerja di dalam sistem pengupahan yang berkesejahteraan dan berkeadilan."

- UUD 1945 hasil amandemen ke II, lihat Sri Sumantri, UUD 1945 Kedudukan dan Aspek-aspek Perubahannya (Bandung: UNPAD Press, 2002), him. 71

${ }^{10}$ UUD 1945 hasil amandemen ke II, Ibid., him. 72

"Perbedaan tersebut adalah pada lingkup terninologi hak, Pasal 27 mengindikasikan hak warga negara sedangkan Pasal 28 adalah hak asasi manusia. Artinya, Pasal 27 sebagai ketentuan yang mengatur hak warga negara sifatnya partikularistik di mana lingkup materinya tertentu dan cenderung ditentukan berdasarkan hasil konsesi politik pembentuk undang-undang (legislator). Berbeda dengan Pasal 27, ־ asal 28 merupakan hak manusia yang bersifat asasi dan kodrati, di mana tiada satu kekuasaan pun yang dapat dibenarkan untuk mereduksi atau mengeksploitasin; s. Lihat Moh. Mahfud MD, "Politik Hukum Hak Asasi Manusia di indonesia," dalam Jumal Hukum No. 14 Vol. 7 Agustus 2000. 
Dalam Peraturan Menteri Tenaga Kerja Nomor Per-01/Men/1999 jo Keputusan Menteri Tenaga Kerja dan Transmigrasi No. Kep-226/Men/2000 diatur sistem standarisasi pengupahan dalam bentuk Upah Minimum. Berdasarkan aturan kebijaksanaan Menteri Tenaça Kerja tersebut dan UU No. 22 Tahun 1999 tentang Pemerintahan Daerah, serta Peraturan Pemerintah No. 25 Tahun 2000 tentang Kewenangan Pemerintah dan Kewenangan Propinsi sebagai daerah Otonom, Gubernur Daerah istimewa Yogyakarta selaku Pemerintah Daerah Tingkat I, mengeluarkan Keputusan Gubernur Daerah istimewa Yogyakarta No. 111 Tahun 2000 tentang Penetapan Upah Minimum di Propinsi Daerah Istimewa Yogyakarta Tahun 2001. Di dalam reputusan Gubernur tersebut ditetapkan ¿esar upah minimum di Propinsi Daerah Istimewa Yogyakarta sebesar Rp. 237.500 per bulan. Dengan demikian telah diatur pola standarisasi pengupahan bagi pekerja di D.I.Y., yang sehai.jsnya menjadi rujukan dalam sistem pengupahan di setiap badan usaha. Ketentuan ini hanya menggariskan minimal sistem pengupahan dan bukan mematok sistem upah dengan jumlah demikian. Dasar pemikiran penetapan sistem UMR ini agar para badan usaha tidak menggaji pekerja dengan upah lebih rendah sehingga ditetapkanlah standardisasi UMR tersebut. Akan tetapi realitasnya sistem UMR ini dipahami oleh kebanyakan badan usaha sebagai suatu pola maksimum pengupahan terhadap beberapa jenis pekerjaan dengan kualitas tertentu. Terhadáp kelemahan ini beberapa pakar hukum menyarankan agar pola pengupahan menggunakan sistem upah maksimum regioal. Tujuannya, agar tingkat kesejahteraan pekerja lebih terpenuhi. Apabila kesejahteraan terpenuhi dengan demikian produktivitas kerja akan lebih baik.

\section{Sekilas tentang Kondisi Sosial dan Ekonomi Masyarakat Kotagede Yogyakarta}

\section{A. Sosio-historis Kotagede Yogyakarta}

Sudah sejak akhir abad ke-17 Kotagede nampaknya telah memperoleh dua keistimewaan besar yang abadi: tempat makam raja dan pusat industri serta perdagangan pribumi. Sebagai tambahan untuk nama umum pertamanya, Mataram, kota itu dikenal dengan nama "Kutha Gedhen dalam bahasa Jawa kasar (Ngoko) atau "Kitha Ageng" dalam bahasa Jawa halus (Kromo), keduanya berarti "kota besar," atau dengan nama lainnya, "Pasar Gedhen (pasar besar) dalam bahasa Jawa kasar, sering selanjutnya disingkat sebagai "Sargedhe. ${ }^{12}$ Antara 1825-1830, sebagian besar daerah Jawa Tengah terlibat perang Diponegoro. ${ }^{13}$ Tetapi, menurut riwaya! setempat, Kotagede luput dari perang. Agaknya kota ini mienerima dorongan baru selama perang karena sejumlah besar pengrajin dan pedagang dari pasar pusat Yogyakarta mengungsi ke kota itu dan banyak di antaranya menetap dan tinggal di sana sesudah perang.

${ }^{12}$ Lhat van Mook (1958 (1926a dan 192.6b)) dan OMalley (1977) dalam Mitsuo Nakamura, Bulan Muncul dari Balik Pohon Beringin (Studi tentang Pergera'kan Muhammadiyah di Kotagecis), citerjemahkan oleh Yusran Asrofie, (rogyakarta: Gadiah Mada University Press). hlm. 12

${ }^{13}$ Tentang Perang Diponegoro lihat Kumar (1972), Rickiefs (1974) dan Carcy (1974a-1974b), ibid. 
Setelah 1972, sebagian besar daerah Kotagede secara administratif masuk kota Yogyakarta sebagai Kemantren Kotagede dan selainnya masuk Kabupaten Bantul. Sungai Gajah Wong, anak sungai Opak, merupakan batas alamiah antara kota tua Yogyakarta dan Kotagede serta memberikan suplai air yang berlimpah untuk irigasi sawah Padi dan Tebu yang meliputi sebagian besar tanah datar daerah tersebut.

Susunan kota ini mencerminkan aslinya pada abad ke-16. Tetapi sekarang pusat geografis kota ini bukan di tempat di mana kraton dulu terletak, tetapi pasar. Pasar ini tidak hanya secara fisik besar bagi ukuran lokal Kotagede tetapi juga tempat yang sibuk didatangi oleh ratusan orang setiap hari dan oleh ribuan orang pada setiap hari pasaran Legi, mingguan Jawa dengan putaran setiap lima hari.

Banyak orang-orang Kotagede menyatakan bahwa cara penghidupan mereka secara turun-temurun bukanlah dari pertanian. Mayoritas menyadari bahwa kedudukan nenek moyang mereka di dalam masyarakat Mataram adalah sebagai abdi dalem karya "pengrajin di dalam dinas kerajaan" atau "tukang kraton." Para pengrajin ini nampaknya dikumpulkan di Kotagede ketika istana kerajaan Mataram didirikan di sana. Namanama kampung tertentu di Kotagede memberi kesan berbagai macam spesialisasi yang mungkin telah ada sejak periode awal sejarah kota itu. Untuk menyebut beberapa contoh. Mranggen memperoleh namanya dari maranggi atau "pembuatan sarung keris," Pandeyan dari pandhe atau "tukang besi,"
Sayangan dari sayang atau "barang tembaga," Samakan dari samak atau "kerajinan kufit," Kemasan dari kemasan atau "tukang emas," dan Jagalan dari jagal atau "penyembelihan. ${ }^{14}$

Ada sejumlah legenda lokal tentang para pengrajin yang memiliki kepandaian istimewa di dalam kerajinan tangan itu, seringkali mereka menganggap bahwa keahlian yang mereka miliki merupakan keahlian yang diwariskan dari para leluhur mereka secara mistik atau memperoleh dengan sendirinya melalui keajaiban atau trick. Sejumlah pedagang pertama juga dikatakan mempunyai intelegensi dan pengetahuan istimewa di dalam perdagangan yang asalnya juga dihubungkan dengan sumber supranatural.

Pada periode-periode awal sejarah kota itu, pendukung terbesar dari para pengrajin dan pedagang Kotagede tentu saja berasal dari pihak istana kerajaan dan para pejabatrija yang membutuhkan barang kerajinan ya:ly memiliki nilai istimewa, keris, pedang, tombak, perhiasan emas, perak, tembaga, permata, perabot yang halus, alat musik, kereta dan semacamnya sebagai perlengkapan atas pangkat dan kekuasaan mereka. Kotagede adalah salah satu temfat di mana barangbarang ini diproduksi secara tradisional.

Dari gambaran historis singkat di atas dapat disimpulkan bahwa Kotagede merupakan nama kota (kecamatan) yang erat dan lekat dengan aktivitas perdagangan serta industri (kerajinan). Sejak semula Kotagede diposisikan sebagai salah satu tempat persinggahan dan tempat memproduksi kerajinan-kerajinan logam yang memiliki nilai magis dan sakral

\footnotetext{
${ }^{14}$ Lihat Tedjo, 1970, ibid., hIm. 14.
} 
bagi para pejabat istana kerajaan Mataram. Sampai saat ini Kotagede identik pusat pasar industri kerajinan, utamanya sejenis logam seperti kuningan, tembaga, dan perak. Kiranya, nilai historis inilah yang memberi julukan atau identitas Kotagede sebagai Kota Perak.

Secara keseluruhan luas wilayah Daerah Istimewa Yogyakarta $3.185,81 \mathrm{~km} 2$, terbagi dalam satu daerah Kotamadya dan empat Kabupaten dengan luas masing-masing: ${ }^{15}$

a. Kotamadya Yogyakarta: $30,50 \mathrm{~km} 2$, yang terbagi dalam 14 kecamatan dan 163 rukun kampung.

b. Kabupaten Sleman: $574,82 \mathrm{~km} 2$, terdiri dari 17 kecamatan dan 86 kelurahan.

c. Kabupaten Bantul: $506,85 \mathrm{~km} 2$, terdiri dari 17 kecamatan dan 75 keluratian.

d. Kabupaten Kulonprogo: $586,28 \mathrm{~km} 2$, terdiri dari 12 kecamatan dengan 88 kelurahan.

e. Kabupaten Gunung Kidul: 1485,36 km2, terdiri dari 13 kecamatan dengan 144 kelurahan.

Kotagede merupakan satuan wilayah kecamatan yang masuk dalam satuan wilayah pemerintahan Kotamadya Yogyakarta. Jumlah luas keseluruhan wilayah kecamatan Kotagede sebanyak $307,0915 \mathrm{Ha}$. Jumlah luas areal wilayah tersebut terdiri dari ${ }^{16}$ tanah sawah . $38.7375 \mathrm{Ha}$ dan tanah kering $261.4012 \mathrm{Ha}$.

Dari luas areal wilayah dengan komposisi jenis tanah dan tekstur fungsi tanah di atas dapat diketahui bahwa tanah sawah lebih sempit daripada luas tanah. kering. Keadaan ini tidak memungkinkan bagi masyarakat Kotagede untuk menanamkan keseriusan mata pencariannya pada jenis cocok tanam atau pertanian. Alhasil dari kondisi tekstur tanah demikian masyarakat lebih memilih tinggal dipinggiran kota dan pusat kota Kotagede dan memilih berternak, berdagang dan atau mengelola usaha jenis kerajinan seperti kerajinan logam ketimbang harus bertahan di desa dengan lahan kering yang sangat terbatas untuk jenis tanaman.

Dari ,segi jumlah kependudukan, berdasarkan hasil sensus penduduk 2002, penduduk Kecamatan Kotagede secara keseluruhan 30.409 orang. Jumlah laki-laki sebanyak 15.235 orang dan perempuan 15.174 orang. Jumlah penduduk tersebut terbagi ke dalam 6.754 KK. Dari sudut kepadatan penduduk Kotagede hasil sensus 2002 berjumlah 9.902 jiwalkm, dan menyebar secara tidak merata.

Gambaran mutasi penduduk Kotagede diuraikan dalam tabel berikut ini.

Tabel I

\begin{tabular}{llccc}
\hline No & Jenis mulasi & Laki-laki & Perempuan & Jumlah \\
\hline 1 & P. A. Kec. & 2 & 2 & 4 \\
2 & P. A. Kab. & 5 & 8 & 13 \\
3 & P. A. Prop. & 5 & 4 & 9 \\
4 & D. A. Kab/kota. & 4 & 4 & 8 \\
5 & D. A. Prop. & 24 & 14 & 38 \\
6 & Lahir & 15 & 7 & 22 \\
7 & Meninggalmati & 6 & 3 & 9 \\
\hline
\end{tabular}

P.A.Kec: Pindah antar kecamatan

P. A. Kab: Pindah antar kabupaten/kota

P. A. Prop: Pindah antar propinsi

D. A. Kab/kota: Dalang antar kabupaten/kota

D. A. Prop: Datang antar propinsi

\footnotetext{
${ }^{15}$ Mònografi D.I.Y.1979, (Kanlor Pusat Data Prov. D.I.Y.), hlm. 3.

${ }^{16}$ Dafa Monografi Kecamatan, (Kecamatan Kotagede Yogyakarta, Semester II, ¿G02), hlm. 1-2.
} 
Dari uraian data mutasi di atas dapat diketahui bahwa pertambahan penduduk Kotagede terus mengalami peningkatan. Hal ini disebabkan angka mobilisasi khususnya penduduk (pendatang) dari provinsi lain yang terus bertambah dari tahun ke tahun. Mobilisasi penduduk (pendatang) ini memang sulit dihindari karena beberapa alasan: 1) tugas belajar 2) ikatan perkawinian 3) PNS yang mengalami mutasi 4) ekspansi perusahaan transnasional.

\section{B. Home Industri Tembaga Kotagede}

Klasifikasi penduduk menurut mata pencaharian digambarkan dalam tabel berikut ini."

Tabel II

\begin{tabular}{llc}
\hline No & Jenis Mata Pencaharian & Jumlah/org \\
\hline 1 & Pelani & 105 \\
2 & Pengusaha besar dan sedang & 35 \\
3 & Pengrajin industri kecil & 498 \\
4 & Buruh industri & 3.004 \\
5 & Buruh bangunan & 502 \\
6 & Pedagang & 2.590 \\
7 & PNS & 1.812 \\
8 & Pensiunan PNS dan TNIPoli & 529 \\
9 & Peternak & 11177 \\
\hline
\end{tabular}

Sebagaimana telah diuraikan pada butir 1 di atas, bahwa jenis tanah dan tekstur fungsi tanah wilayah Kecamatan Kotagede ikut mempengaruhi peta perekonomian masyarakat. Dengan tanah kering seluas $261.4012 \mathrm{Ha}$ lebih luas daripada tanah sawah 38.7375 Ha maka masyarakat lebih banyak memilih mata pencaharian kerajinan industri kecil, menjadi buruh industri, berdagang; dan bertemak. Jenis mata pencaharian ini sudah barang tentu menempati peringkat terbanyak di samping PNS.

Secara teoritis, terdapat 4 klasifikasi bentuk usaha dilihat dari segi jumiahnya: ${ }^{18}$

1. Industri besar adalah perusahaan yang mempunyai pekerja 100 orang lebih.

2. Industri sedang adalah perusahaan yang mempunyai pekerja 20 - 99 orang

3. Industri kecil adalah perusahaan yang mempunyai pekerja 15-19 orang

4. Industri rumah tangga adalah usaha yang mempunyai pekeja 1 - 4 orang.

Dan pelaku jenis usaha kerajinan tembaga di Kotagede termasuk empa! kelompok usaha di atas. Secara keseluruhari, jenis usaha ini lebih banyak digerakkan oleh home-home industri ketimbang perusahaan besar.

Untuk mendapatkan peta permasalahar secara komprehensif seputar kesehatar. lingkungan kerja maka lingkup sistem usaha produksi industri kerajinan tembaga harus dilihat secara menyeluruh mulai dari rangkaian industri kerajinan-tembaga, pola hubungan kerja dan asoek kontrak dalam rangka pertindungan kesenatan pekerja antara perusahaan besar sampai pada home-home industri dengan para pekeja.

Baik industri besar maupun home industri, semuanya melakukan serangkaian kegiatan usaha yang meliputi penyediaan bahan baku, proses produksi, dan pemasaran. Perbedaannya hanya pada modal dan jangkauan pemasaran.

\section{${ }^{17}$ Ibid., hilm. 27}

${ }^{18}$ Ray Darville, "The Environment as A Social Issue", dalam Analizing Social Problem (New Jersey: Prentice Hall, Inc., 1997). 
Bagi industri besar seperti Tom's Silver, Ansor's Silver, Narti's Silvers, dan HS Silver daya jangkau pemasaran tidak hanya lokal domestik saja melainkan antar provinsi sampai mancanegara. Hal demikian tidak terjadi pada home-home industri. Dalam kegiatan proses produksi, home-home industri tidak berdiri sendiri melainkan memiliki jalinan kemitraan dengan perusahaan besar di atas. Bentuk kemitraannya adalah jasa tenaga kerja. ${ }^{19}$ Artinya, home industri berkedudukan sebagai penyedia jasa (tenaga pengrajin) yang siap mengasah bahan mentah tembaga sampai bahan setengah jadi atau jadi. Setengah jadi artinya bahan-bahan tembaga diproses hanya sampai pada tahap ukir (bentuk) barang sesuai motif pesanan. Sedangkan bahan jadi artinya bahan tembaga sudah diproses sampai tahap finishing, yaitu tahap ukir, penghalusan sampai pewarnaan menjadi barang yang bernilai artistik dan konsumeristik. Jalinan mitra usaha antara keduanya sangat tergantung pesanan atau permintaan dari industri besar tentunya.

Atas dasar hubungan demikian, maka hubungan kerja antara usaha besar dengan home-home industri sangat terbatas. Artinya, hubungan hanya sebatas pada pemborongan barang dengan jasa semata. Adapun implikasi akibat proses keija dan jaminan perlindungan kerja bagi-bagi home industri tidak ada. Dan ini berlangsung terus-menerus sampai turuntemurun.

Dalam dunia industri kerajinan tembaga di Kotagede yang notabene kebanyakan dikelolah oleh para home-home industri, aktivitas kejja sudah barang tentu terpusat di rumah-rumah keluarga pribadi pekerja. Kebanyakan pekerja menyekat ruang dapurnya $4 \times 5 \mathrm{~m}^{2}$ untuk dijadikan ruang konsentrasi pekejaannya. Pekerja socara total menghabiskan rata-rata -16 jam untuk mengejar target borongan dán setoran. Bahkan di tengah keremangan malam para pekerja harus ngelembur tanpa memperhitungkan kesehatan fisik. Aktivitas ini menjadi potret realitas masyarakat Kotagede sehari-hari di tengah keramaian sanjungan sebagai kota perak dan obral pemerintah guna mengeruk kocek para turis.

1. Proses Produksi dan Aspek Kesehatan Lingkungan Kerja

\section{a. Bahan-bahan/alat}

Sebelum memulai proses pekerjaan ini, terlebih dahulu dipersiapkan bahan-bahan atau alat sebagai berikut.

1) Kepingan tembaga;

2) Pola atau motif ukir,

3) Batu hias sebagai permata atau perniks;

4) Cat cair atau pewama

5) Air raksa;

6) Alat-alat (perangkat keras/hardware);

a) Pembakar: Gembusan, Bensin, Sepuyer,

b) Pemotong: Gunting, Martel;

c) Pemuter kawat tembaga: Joro;

b. Cara Pembuatan ${ }^{20}$

1) Sebelum memulai pekerjaan proses pembuatan barang ukir dari bahan logam Tembaga ini, Pengrajin telah memperoleh atau mendapatkan bahan logam tembaga

\footnotetext{
${ }^{19}$ data ini diperoleh melalui observasi dan wawancara langsung dengan Bp. Toyo salah satu pekeria home industri tembaga, tanggal 20 Juni 2003.

${ }^{20}$ Wawancara dengan lbu Jarwo, seorang pengrajin usaha tembaga, 5 Juli 2003
} 
berbentuk kepingan yang diperoleh dari pemesan atau langsung dari toko.

2) Sebelum proses dimulai, Pengrajin terlebih dahulu mempersiapkan pola-pola ukir yang digunakan sebagai motif ukiran tembaga.. Bentuknya bermacam-macam, ada pola hiasan dinding seperti kaligrafi, bunga, hewan dsb; - pola miniatur candi, andong, sepeda motor, sepeda ontel kuno, dsb; pola pas bunga, pola perangkat dapur seperti periuk, kendi, ceret, dsb; pola pengaman kendaraan sepeda motor seperti helm, atau pola perhiasan seperti giwang, kalung, cincin, mahkota, dan masih banyak yang lainnya.

3) Agar tembaga dapat dibentuk dengan lunak dan mudah, kepingan tembaga terlebih dahulu dibakar. Dalam proses pembakaran inilah seharusnya pekerja menggunakan alat pelindung seperti masker agar limbah kimia efek dari proses pembakaran logam jenis ini tidak tidak terhirup langsung oleh paru-paru.

4) Setelah proses pembakaran selesai, selanjutnya kepingan tembaga digunting sesuai pola yang dimaksud.

5) Di tempat terpisah, tembaga-tembaga yang berbentuk satuan kawat adakalanya tetap dibutuhkan guna membentuk satuan hias dalam ukuran kecil seperti anting atau tempat mata konde atau cincin.

6) Setelah kepingan tembaga selesai diukir dalam satuan yang terpisah-pisah, selanjutnya dilakukan proses pembakaran kedua. Pada tahap ini, proses pembakaran berfungsi sëbägai penyatuan produk yang terpisah-pisah tadi menjadi satu bentuk barang yang sempuma dalam arti bentuk bukan rupa.

7) Baru setelah proses pembakaran kedua ini, dilakukanlah perendamandalam wadah yang berisi air raksa (yang berisi cairan air, nekel, dan klorid). Proses perendaman ini sangat berbahaya karena mengandung zat kimia yang pekat. Proses perendaman ini berlangsung satu malam ringga wama berubah wama nekel atau monel.

8) Untuk mendapatkan warna putih (perak), barang tembaga yang sudah jadi warna nekel tersebut dimasukan ke dalam larutan air, perak, dan potas, ditunggu sampai wama berubah wama perak.

9) Untuk mendapatkan warna emas, barang yang sudah jadi warna putih dimasukkan ke dalam larutan air, emas, dan potas, ditunggu sampai warna berubah warna emas.

10) Proses terakhir yaitu pencucian. Setelah pencucian langsung dijemur.

Analisis Yuridis terhadap Aspek Kesehatan Lingkungan Kerja dan Perlindungan Kesehatan Pekerja Home Industri Tembaga di Kotagede Yogyakarta

Berdasarkan hasil pendataan industri 2002 yang dilakukan oleh Pemerintah Kota Kecamátan Kotagede di dua kelurahan, yakni Kelurahan Prenggan dan Purbayan dapat diketahui bahwa jenis usaha ini memiliki limbah akan tetapi jenis, volume. IPAL, dan upaya penanganannya belum tertangani secara baik. Dari data yang diperoleh -khusus data limbah industri-terlihat bahwa para pengusaha memberi keterangan tidak sempuma dan bahkan hampir dalam bagian kolom ini yang tidak diisi sama sekali. Ketidaksempumaan atau pengosongan kolom 
ini ditengarai beberapa faktor.

1. Khusus limbah industri ini memang belum ada sistem penanganannya secara komprehensif oleh dinas setempat. Kesulitan penanganan dikarenakan bidang usaha ini kebanyakan dikelolah oleh home-home industri yang dalam proses pendirian usahanya tidak memerlukan sistem manajemen pengendalian dan pengawasan melalui izin usaha sebagaimana industri menengah dan besar lainnya. Akibatnya pembuangan limbah dilakukan oleh pengusaha sendiri dengan caranya sendir tanpa memperdulikan aspek kesehatan lingkungan kerja dan. perlindungan kesehatan pekerja. ${ }^{21}$

2. Faktor kesengajaan Pengusaha untuk meminimalisasi biaya tambahan produksi dan menghindari risiko biaya produksi. Salah satu kelemahan dalam penegakan sistem pengendalian kesehatan lingkungan kerja dan perlindungan kesehatan pekerja karena perangkat peraturan daerah yang belum selengkapnya mengatur perihal ini. Padahal di era desentralisasi dengan titik berat otonomi luas pada kabupaten dan kota, seperangkat peraturan kebijaksanaan ini sangat dibutuhkan. Jika pun seperangkat peraturan perundangundangan pusat telah dibentuk -seperti UU No. 23 Tahun 1992, UU No. 23 Tahun 1997, UU No. 1 Tahun 1970, Keputusan
Menteri Kesehatan No. 149/Menkes/SK II/ 1994, Keputusan Menteri Tenaga Kerja dan Transmigrasi No. 241/MEN/2000, instruksi Menteri Tenága Kerja No. INS03/M/BW/1991, Keputusan Menteri Tenaga Kerja No. Kep.72/Men/1984 jo Keputusan Menteri Tenaga Kerja No. 608 I Men/1986, Peraturan Menteri Tenaga Kerja No. Per-01/Men/1999 jo Keputusan Menteri Tenaga Kerja dan Transmigrasi No. Kep-226/Men/2000 akan tetapi implementasi di lapangan tetap membutuhkan seperangkat aturan yang spesifik teknis administratif. Alasannya, karena masyarakat daerah lebih paham persoalan riil daerahnya.

Dari hasil identifikasi Peneliti' terhadap beberapa pengusaha home industri tembaga di Kotagede terdapat tiga typekal pengusaha: (1) Pengusaha yang mengetahui tetapi tidak memiliki kesadaran akan tanggung jawab; (2) Pengusaha yang memang tidak tahu sama sekali (golongan ini kecil kemungkinan), dan dengan demikian ia tidak memiliki kesadaran; (3) Pengusaha yang mengetahui dan memiliki kesadaran yang tinggi pula (akan tetapi jumlah ini sedikit sekali).22 Memang agak sulit menentukan faktor mana dari kedua faktor di atas yang paling mempengaruhi kelemahan penegakan sistem pengendalian kesehatan lingkungan dan

2' Wawancara dengan Bp. Priatna Kabid. Pengawasan pembangunan Kecamatan Kotagede, tanggal 10 Juni 2003.

${ }_{22}$ Parameter ini dapat dilihat dalam teori konsep manusia menurut Erich Fromm, dalam Erich Fromm, Konsep Manusia Menunt Marx (Ed. Kamdani), (Yogyakarta: Pustaka Pelajar, 2001). Lihat juga Paulo FreireFreire, Sekolah Kapitalisme yang Licik(Yogyakarta: LKIS, 1998). 
perlindungan kesehatan pekerja. Karena antara kedua faktor tersebut saling mempengaruhi (korelasi). Ketiadaan sistem manajemen pengendalian limbah oleh dinas pemerintahan semakin memberi peluang bagi pengusaha untuk mereproduksi limbah dengan leluasa. Akibatnya, pengusaha tidak memiliki sense atau kepekaan sosial dan moral sama sekali untuk bertanggung jawab atas segala aktivitas industri dalam merauk keuntungan usahanya.

3. Situasi ini bak "gayung bersambut" ketika pekerja atau pengrajin sendiri apatis terhadap persoalan semua itu. Karena mereka memang memilih profesi ini sebagai keterpaksaan akibat sulitnya mencari pekerjaan lain. Meskipun Pekerja mengetahui efek dari pekerjaannya akan tetapi faktor keterbelakangan ekonomi memaksa mereka untuk menerima apa adanya.

Dari hasil observasi menunjukkan bahwa $98 \%$ lingkungan kerja home-home industri tembaga di Kotagede tidak memperhatikan aspek kesehatan lingkungan dan periindungan kesehatan pekerja dalam pengertian yang lebih luas. Para pekerja tidak diberi sosialisasi seputar proses produksi dan dampaknya bagi kesehatan. Padahal dalam Pasal 5 UUPLH ditegaskan bahwa setiap orang mempunyai hak yang sama atas lingkungan hidup yang baik dan sehat.

Kata "setiap orang" mengandung pengertian universal, dan pekerja termasuk di dalamnya. Ketentuan ini memperjelas pondasi bagi bangunan perlindungan hak pekerja baik berupa lingkungan yang sehat maupun kesehatan fisik, rohani dan sosial. Dari ketentuan ini juga dapat di-mafhum-kan bahwa kewajiban setiap pemilik usaha mengupayakan kesehatan lingkungan kerja dan perlindungan kesehatan pekerja sebagaimana ditegaskan dalam Pasal 23 UUK. Dalam rangka pemberian hak tersebut pengusaha diwajibkan memberi layanan informasi seputar ruang lingkup kerja secara komprehensif, benar dan objektif (Pasal 6). Dalam penjelasan Pasal 6 ditegaskan bahwa, hak atas informasi lingkungan hidup merupakan suatu konsekuensi logis dari hak berperan dalam pengelolaan lingkungan hidup yang berlandaskan pada asas keterbukaan. Hak atas informasi lingkungan hidup akan meningkatkan nilai dan efektivitas peraniserta dalam pe'ngelolaan lingkungan hidup, di samping akan membuka peluang bagi pekerja untuk mengaktualisasikan haknya atas lingkungan hidup yang baik dan sehat.

Di sisi lain, sistem dan tawaran kerja yang tidak teratur sering terjadi bahkan menjadi pola tetap dalam lingkungan kerja home industri tembaga Kotagede. Keadaan ini jelas mempengaruhi pola kerja dan tingkat pendapatan pekerja. Kesehariannya, hampir seluruh waktu pekerja dihabiskan untuk bekerja, mulai dari pukul 8.30 pagi sampai 10.00 malam. Berjam-jam menghirup debu logam tembaga, uap air raksa, arsen, nikel dan zat pewama lainnya tentu berbahaya. Gejala penyakit yang ditimbulkan mulai dari pnemonitis, silikosis, sampai bronkhitis. Ditinjau dari sudut yuridis, kebiasaan tersebut sudah barang tentu menyimpang dari ketentuan Instruksi Menteri Tenaga Kerja No. INS-03/M/BW/1991 tentang Pelaksanaan Waktu Kerja dan Waktu Istirahat, yang menegaskan bahwa agar setiap perusahaan tidak mempekerjakan pekerja lebih dari 9 jam 
sehari dan 54 jam seminggu. Apabila suatu perusahaan terdapat mempekerjakan pekerja melebihi dari waktu yang telah ditentukan maka perusahaan tersebut harus mengarahkan sebagaimana ketentuan tersebut di atas dan memperhitungkan upah lembur berdasarkan Keputusan Menteri Tenaga Kerja No. Kep. 72/Men/1984 jo Keputusan Menteri Tenaga Kerja No. 608I Men/1986. Namun sayangnya, dalam sistem borongan kerja di lingkungan home industri tembaga tersebut, upah lembur tidak dikenal. Harga borongan kerja telah ditetapkan sejak awal tanpa memperhitungkan lemburan per jam. Demikian pula risiko kerja tidak mendapat perhitungan sama sekali.

Apabila diruntut secara menyeluruh, terdapat 5 hal yang luput dari perhatian pengusaha dalam upaya menjaga kesehatan lingkungan dan perlindungan kesehatan pekerja:

(1) sosialisasi seputar ruang lingkup kerja, proses produksi, dan dampak limbah industri;

(2) Pemberian informasi sarana perlindungan kesehatan kerja, seperti masker, sarung tangan dan lain sebagainya;

(3) pelayanan jaminan sosial tenaga kerja;

(4) mempertahankan ruang kerja agar tetap bersih, sehat, tidak monotoni, dan pengaturan ventilasi udara yang cukup bagi pergantian udara yang kotor dan bersih;

(5) Pengaturan jam kerja tidak melebihi 9 jam sehari atau 54 jam seminggu;

(6) sistem pengupahan yang mampu mensejahterakan kehidupan secara layak sebagai manusia.

Keadaan ini sangat memprihatinkan, namun anehnya para pekerja tetap bertahan di tengah ketakberdayaannya.

Ada beberapa faktor yang melatar belakangi, mengapa hubungan kerja ini begitu kuat meskipun hak-hak normatif pekerjapekerja home industri seperti hak kesehatan lingkungan kerja dan perlindungan kesehatan pekerja diabaikan:23

\section{1. faktor keterpaksaan}

Para responden mengemukakan bahwa kesulitan mencari pekerjaan menjadi penyebab keterpaksaan meréka untuk menjalani profesi ini. Akses informasi peluang kerja yang terbatas, pengalaman, pendidikan, serta latar belakang ekonomi yang rendah, mendesak serta memicu mereka untuk bertahan memilih profesi ini. Dengan situasi keterpaksaan ini, mereka tidak memiliki nilai tawar dan selalu menerima apa adanya. Bahkan menurut Bp. Soepriono, ${ }^{24}$ dalam pembayaran jasa, Juragannya tidak membayar secara tepat waktu dan profesional. Sistem dan cara pembayarannya tidak pasti (waktu).

\section{2. faktor turun-temurun}

Keahlian yang dimiliki para pekerja di bidang ini ternyata merupakan keahlian yang diturunkan secara turun-temurun. Latar belakang ini mendorong minat para cucu dari leluhur sebelumnya, memilih dan meneruskan

${ }^{23}$ Data diperoleh dari koesioner, 22 Juni 2003.

${ }^{24}$ Responden, wawancara pada 21 Juni 2003. 
profesi ini sebagai identitas atau simbol sosial. Meskipun secara finansiil, pendapatan profesi ini tidak pasti akan tetapi nilai historis dan dimensi simbol sakral dan sosial membuat para pekerja legowo atau lapang dada menikmatinya. Latar belakang tersebut menyebabkan garis hubungan kerja antara kawulo dan gusti semakin kuat dan dalam.

3. faktor tingkat kesadaran pekerja yang rendah

Para responden sendiri mengakui bahwa terdapat perubahan kesehatan setelah mereka menjalani profesinya, seperti sering batuk, sesak napas, paru-paru, radang tenggorokkan sampai pegel sekitar punggung. Dengan jam kerja yang tidak tentu sekitar 1518 jam perhari, sudah pasti tingkat kerawanan kesehatan sangat rentan dari proses kimiawi. Akan tetapi macam penyakit ini tidak mereka pahami sebagai sesuatu yang membahayakan dan upaya maksimal yang mereka lakukan hanya kejja hati-hati. Makna hati-hati itu sendiri tidak mereka pahami lebih dalam.

Upaya Menjamin Kesehatan Lingkungan Kerja dan Perlindungan Kesehatan

Pekerja Home Industri Tembaga Kotagede Yogyakarta

Kesehatan lingkungan kerja diselenggarakan untuk mewujudkan produktivitas kerja yang optimal. Kesehatan kerja meliputi pelayanan kesehatan kerja, pencegahan penyakit akibat kerja, dan syarat kesehatan kerja. Untuk mewujudkan tujuan tersebut maka setiap tempat kerja wajib menyelenggarakan upaya kesehatan dengan pendekatan pemeliharaan, peningkatan kesehatan (promotif), pencegahan periyakit (preventif), penyembuhan penyakit (kuratif), dan pemulihan kesehatan (rehabilitasi) yang dilaksanakan secara menyeluruh, terpadu, dan berkesinambungan.

Sebagaimana telah sebagian diuraikan pada bab sebelumnya, bahwa di dalam menyikapi kesehatan lingkungan kerja yang semakin buruk, ada beberapa teknik penyehatan yang memerlukan prioritas dan ditujukan untuk:

1. Pengendalian pencemaran lingkungan.

2. Peningkatan hygiene perusahaan dan kesehatan/keselamatan kerja di dalam ruang lingkup lingkungan keja.

3. Jaminan perlindungan kesehatan dan keselamatan pekerja akibat penyakit kerja.

Karena kesehatan lingkungan kerja home industri dipengaruhi oleh banyak faktor, maka sudah barang tentu langkah-langkah sistem manajemen pengendalian kesehatan lingkungan kerja ini juga harus melibatkan banyak subjek dan cara. Dilihat dari sudut subjek (stakeholders) yang secara yuridis memegang peran dan tanggung jawab yang terbesar dan terdekat, maka dapat diklasifikasi menjadi tiga: 1) Pemerintah, 2) Perusahaan atau pengusaha, 3) masyarakat (LSM, Perguruan Tinggi, dan masyarakat pekerja itu sendiri). Dari tiga klasifikasi subjek ini akan dibahas secara langsung dan sistematis langkah-langkah yang harus dilakukan dalam upaya pengendalian kesehatan lingkungan kerja dan perlindungan kesehatan pekerja.

1. Sistem Manajemen Pengendalian Kesehatan Lingkungan Kerja Oleh Pemerintah

Berangkat dari persoalan ketiadaan sistem pengendalian limbah home industri tembaga oleh pemerintah selama ini dan sulitnya menerapkan pola pengawasan 
melalui sistem perizinan karena usaha inii dijalankan oleh kebanyakan pengusaha kecil dan menengah maka langkah strategis yang efektif diterapkan adalah sebagai berikut.

Pertama, melalui Pemerintah Daerah Tingkat II menetapkan sebuah peraturan kebijaksanaan yang materie!nya mengatur sistem pengendalian kesehatan lingkungan kerja dan pekerja. Mengapa stakeholders yang utama adalah Pemerintah Daerah Tingkat II? Karena hal ini mendasarkan pada UU No. 22 Tahun 1999 jo Peraturan Pemerintah No. 25 Tahun 2000, di mana titik berat otonomi ada pada Pemerintah Kabupaten dan Kota, sedangkan kedudukan dan fungsi Gubernur selaku Kepala Daerah Tingkat ! hanya bersifat lintas kabupaten atau sektoral, la tidak lagi saling membawahi dalam arti chierarkis/ subordinatif. Penetapan materi pengaturan sistem pengendalian kesehatan lingkungan kerja dan pekerja sesungguhnya secara tidak langsung telah memperoleh payung undangundang, di antaranya berdasarkan UU No. 23 Tahun 1992 jo Keputusan Menteri Kesehatan No. 149/MENKES/SK/II/1994, UU No. 23 Tahun 1997, dan UU No. 1 Tahun 1970 jo Keputusan Menteri Tenaga Kerja dan Transmigrasi No. Kep. 241/MEN/2000 tentang Petunjuk Pelaksanaan Bulan Keselamatan dan Kesehatan Kerja 2001, yang kesemuanya mengisyaratkan perlunya menjaga dan menegakkan kesehatan lingkungan pada umumnya dan lingkungan kerja pada khususnya.

Kedua, adapun materinya (sistem pengendalian kesehatan lingkungan kerja dan pekerja) dapat dilakukan beberapa langkah altematif sebagai berikut.

a. Pembinaan/penyuluhan terhadap perusahaan/tempat keja, tenaga kerja dan pengguna produksijjasa terutama di sektor yang rawan kecelakaan.

b. Penyebarluasan kegiatan dengan 2 cara: 1) langsung (pembentukan badan panitian triparteit yang terdiri dari perwakilan struktur pemerintah, perusahaan, dan pekerja atau masyarakat; 2) tidak langsung, melalui media cetak, radio, televisi dll.

c. Evaluasi

2. Sistem Manajemen Pengendalian Kesehatan Lingkungan Kerja Oleh Perusahaan

a. Substitusi, yaitu mengganti bahan yang lebih berbahaya dengan bahan yang kurang bahayanya atau tidak .berbahaya sama sekali, misalnya karbon tetraklorida diganti dengan triklor etilen. Atau tronshot dipergunakan sebagai pengganti pasir pada pekerjaan sandblasting.

b. Ventilasi umum, yaitu mengalirkan udara sebanyak mungkin menurut perhitungan ke dalam ruang kerja, agar kadar dari bahan-bahan yang berbahaya oleh pemasukan udara ini lebih rendah dari pada kadar yang membahayakan, yaitu kadar Nilai Ambang Batu.

c. NAB adalah kadar yang padanya atau di bawah dari padanya, apabila pekerjapekerja menghirupnya 8 jam sehari, 5 hari seminggu, tidak akan menimbulkan penyakit atau kelainan.

d. Ventilasi keluar setempat (local exhausters), ialah alat yang biasanya menghisap udara di suatu tempat kerja tertentu, agar bahan-bahan dari tempat kerja tetentu yang membahayakan dihisap dan dialirkan ke luar.

e. Isolasi, yaitu mengisolasi operasi atau 
proses dalam perusahaan yaing membahayakan, misalnya isolasi mesin yang sangat hiruk, agar kegaduhan yang disebabkannya turun dan tidak menjadi gangguan lagi.

f. Pakaian pelindung, misalnya: masker, kacamata, sarung tangan, sepatu, topi pakaian dan lain-lain.

g. Pemeriksaan sebelum kerja, yaitu pemeriksaaan kesehatan kepada calon pekerja untuk mengetahui, apakah calon tersebut serasi dengan pekerjaan yang akan diberikan kepadanya, baik fisik maupun mentalnya.

h. Pemeriksaan kesehatan berkala/ulangan, untuk evaluasi, apakah faktor-faktor penyebab itu telah menimbulkan gangguan-gangguan/kelainan-kelainan kepada tubuh pekerja atau tidak.

i. Penerangan sebelum kerja, agar pekerja mengetahui dan mentaati peraturanperaturan, dan agar mereka lebih berhatihati.

j. Pendidikan tentang kesehatan dan keselamatan pekerja secara kontiniu, agar pekerja-pekerja tetap waspada dalam menjalankan pekerjaannya.

Cara-cara pencegahan di atas bersifat umum, dan perlu diterapkan secara khusus dan terperinci bagi setiap penyakit akibat kerja dengan memperhatikan seluruh situasi dan kondisi secara cermat. Di bawah ini akan diuraikan secara bertahap pelaksanaan upaya pencegahan penyakit akibat kerja.

1) Pencegahan tingkat pertama

1. Health Promotion

Di sini termasuk pendidikan tentang kesehatan, tingkat gizyang baik pengembangan kepribadian, perumahan yang sehat dan memadai, lingkungan kerja yang memadai, penyuluhan dan konsultasi tentang pemeriksaan kesehatan periodik.

\section{Specipic Protection}

Di sini termasuk immunisasi, hygiene perorangan, sanitasi lingkungan, proteksi terhadap bahaya dalam kerja dan proteksi terhadap kecelakaan.

2) Pencegahan tingkat kedua

a) Diagnosa dini penyakit dan pengobatan segera: Di sini termasuk case finding, screening survey, pemeriksaan selektif, isolasi penderita infeksius dan pengobatan yang memadai.

b) Pembatasan ketidakmampuan (disability limitations)

Di sini termasuk penyediaan pelayanan dan fasilitas untuk memberikan pengobatan yang memadai untuk menghentikan proses penyakit dan mencegah timbulnya komplikasi.

\section{3) Pencegahan tingkat ketiga}

Tingkat pencegahan yang ketiga ini adalah rehabilitasi yaitu usaha yang berhubungan dengan penyediaan fasilitas $\mathrm{di}$ rumah sakit dan di dalam masyarakat yang bertujuan untuk pendidikan kembali penderita sehingga kemampuannya dapat digunakan secara maksimal, pendidikan masyarakat dan kalangan industri agar mereka menerima penderita yang sudah direhabilitasi, dan mempekerjakan secara selektif, penderita cacad yang sudah direhabilitasi.

Upaya pencegahan yang umumnya diterapkan di dalam perusahaan industri adalah pencegahan tingkat pertama (health promotion/pendidikan) dan pencegahan tingkat kedua (diagnosa dini penyakit dan pengobatan segera). 
3. Sistem Manajemen Pengendalian Kesehatan Lingkungan Kerja oleh Pekerja Sendiri dan atau Melalui Peran Aktif Masyarakat (LSMI Insan Akademik/ dll)

Salah satu pokok upaya kesehatan adalah kesehatan lingkungan kerja. Kesehatan kerja diselenggarakan untuk mewujuơkan produktivitas kerja yang optimal. Dalam rangka ini, upaya kesehatan kerja dapat juga diselenggarakan oleh pekerja sendiri dan atau masyarakat.

Di dalam Pasal 7 UUPLH ditegaskan bahwa masyarakat mempunyai kesempatan yang sama dan seluas-luasnya untuk berperan dalam pengelolaan lingkungan. Pengelolaan Lingkungan yang dimaksud adalah upaya terpadu untuk melestarikan fungsi lingkungan hidup yang meliputi: kebijaksanaan penataan, pemanfaatan, pengembangan, pemeliharaan, pemulihan, pengawasan, dan pengendalian lingkungan. Selanjutnya dalam pasal yang sama ayat (2) dijelaskan, pelaksanaan pengelolaan lingkungan dilakukan dengan cara:

a. meningkatkan kemandirian, keberdayaan masyarakat, dan kemitraan;

b. menumbuhkembangkan kemampuan dan kepeloporan masyarakat;

c. menumbuhkan ketanggapsegeraan masyarakat untuk melakukan pengawasan sosial;

d. memberikan saran pendapat;

e. menyampaikan informasi dan/atau menyampaikan laporan.

Dari uraian di atas dan melihat potensi yang ada di dalam masyarakat seperti LSM atau lembaga pengabdian masyarakat (LPM) perguruan tinggi negeri ataupun swasta sesungguhnya secara fungsional dapat diarahkan ke sana. Mengintensifkan program konseling baik berbentuk penyuluhan, advokasi, problem solving, pendampingan, maupun penelitian-penelitan ilmiah. Peran ini tidak lain dalam kerangka pemberdayaan dan peningkatan kesadaran masyarakat pekerja (khususnya) agar minimal mereka paham dan peka dengan persoalan-persoalan kesehatan lingkungan kerja di sekitar mereka sendiri. Konteks saat ini seharusnya program-program KKN lebih menitikberatkan pada metode fungsiona! yang melekat erat dengan kebutuhan masyarakat yang dituju, sehingga target sasaran dapat langsung mengena pada kebutuhan esensial masyarakat.

\section{Simpulan}

Dari uraian kajian di atas dapat disimpulkan bahwa:

Pertama, keadaan kesehatan lingkungan kerja dan perlindungan kesehatan pekejja di lingkungan home-home industri tembaga Kotagede cukup memprihatinkan. Faktor pemicunya adalah ketiadaan sistem pengendalian kesehatan lingkungan kerja dan perlindungan kesehatan pekerja baik oleh dinas pemerintah kota setempat maupun pengusaha. Kesulitan peniegakan sistem pengendalian kesehatan lingkungan kerja ini disebabkan oleh para pelaku usaha (pengusaha) mengkategorisasikan jenis usahanya sebagai kelompok usaha kecil di mana untuk memberlakukan sistem perizinan usaha sangat sulit. Faktor lainnya adalah sikap apatisme pekerja akibat keterbatasan skill di bidang lain dan latar belakang ekonomi yang rendah menjadi faktor ketakberdayaan dan keterpaksaan menjalani pekerjaan dan menerima perlakuan -upah rendah dan jam 
kerja melampaui batas undang-undang — apa adanya. Di samping itu, peran LSM dan atau LPM PTN/PTS selama ini juga belum secara fungsional menyentuh kebutuhan esensial masyarakat Kotagede yang mayoritas berlatarbelakang usaha home industri tembaga. Kebanyakan program-program KKN bersifat seremonial formal yang mengutamakan bangunan materiat fisik.

Kedua, menyikapi keadaan kesehatan lingkungan kerja dan perlindungan kesehatan pekerja yang buruk tersebut maka dibutuhkan beberapa teknik penyehatan yang memeriukan prioritas dan ditujukan untuk:

a. Pengendalian pencemaran lingkungan.

b. Peningkatan hygiene perusahaan dan kesehatan/keselamatan kerja di dalam ruang lingkup lingkungan kerja.

c. Jaminan perlindungan kesehatan dan keselamatan pekeja akibat penyakit kerja.

Karena faktor yang mempengaruhi kesehatan lingkungan kerja beragam maka sudah barang tentu langkah-langkah sistem manajemen pengendalian kesehatan lingkungan kerja ini juga harus melibatkan banyak subjek dan cara. Dilihat dari sudut subjek (stakeholders) yang secara yuridis memegang peran dan tanggung jawab yang terbesar dan terdekat, maka dapat diklasifikasi menjadi tiga: 1) Pemerintah, 2) Perusahaan atau pengusaha, 3) masyarakat (LSM, Perguruan Tinggi, dan masyarakat pekerja itu sendiri). Dari tiga klasifikasi subjek ini diharapkan mampu secara efektif mengendalikan kesehatan lingkungan kejia dan perlindungan kesehatan pekerja.o

\section{Daftar Pustaka}

Attamimi, A. Hamid S., Hukum tentang Peraturan Perundang-undangan dan Peraturan Kebijakan (Hukum Tata Pengaturan), Jakarta: FH. UI, 1993.

Data Monografi Kecamatan, Kecamatan Kotagede Yogyakarta, Semester II, 2002.

E, Endan, Pengantar IImu Kesehatan, Bandung: Rineka Cipta, tanpa tahun.

Freire, Paulo, Sekolah Kapitalisme yang Licik, Yogyakarta: LKIS, 1998.

Fromm, Erich, Konsep Manusia Menurut Marx (Ed. Ķamdani), Yogyakarta: Pustaka Pelajar, 2001.

GBHN 1999-2004 (Tap MPR No. IV/MPR/ 1999), Bandung: Pustaka Setia, 2001.

Hardjasoemantri, Koesnadi, Hukum Tata Lingkungan, Yogyakarta: Gadja Mada University Press, 1999.

Luqman, Marcus, Freies Ermessen dalam Proses dan Pelaksanaan Rencana Kota (Penelitian di Kodya Pontianak (1970-1990)), Tesis, Bandung: Unpad, 1989.

MD, Moh. Mahifud, "Politik Hukum Hak Asasi Manusia di Indonesia." Dalam Jumal Hukum No. 14 Vol. 7 Agustus 2000.

Monografi D.I.Y.1979, Kantor Pusat Data ProP. D.IY.

Nakamura, Matsua, Bulan Muncul dari Balik Pohon Beringin (Studi tentang 
Pergerakan Muhammadiyah di Kotagede), Yogyakarta: Gadjah Mada University Press.

Ryadi, Slamet, Kesehatan Lingkungan, Surabaya: Karya Anda, 19840.

Sitepoe, Mangku, Usaha Mencegah Pencemaran Udara, Jakarta: Grasindo, 1997.

Slamet, Juli Soemirat, Kesehatan Lingkungan, UU No. 23 Tahun 1992.

Yogyakarta: Gadjah Mada University UU No. 23 Tahun 1997.
Press, 2002.

Suma'mur, "Berbagai Jenis Penyakit Akibat Kerja dan Tata Cara Pencegahannya," dalam Penyakit Akibat Kerja, Jakarta: Hiperkasi, 1984.

Sumantri, Sri, UUD 1945 Kedudukan dan Aspek-aspek Perubahannya, Bandung: UNPAD Press, 2002.

808080 